${ }^{1}$ Lee, J. B., Covino, B. G., Takman, B. H., and Smith, E. R., Circulation Res., 17, 57 (1965).

${ }^{2}$ Bergström, S., Carlson, L. A., and Orö, L., Life Sci., 6, 449 (1967).

${ }^{3}$ Horton, E. W., and Jones, R. L., Brit. J. Pharmacol., 37, 705 (1969).

4 Bergström, S. H., Dunér, H., von Euler, U. S., Pernow, B., and Sjövall, J., Acta Physiol. Scand., 45, 145 (1959).

${ }^{5}$ Lee, J. B., in Prostaglandins, Nobel Symposium II (edit. by Almqvist and Wicksell), 197 (Interscience, Stockholm and New York, 1967).

${ }^{6}$ Westura, E. E., Kannegiesser, H., O'Toole, J. D., and Lee, J. B., Circulation Res. (in the press).

${ }_{7}$ Strong, C. G., and Bohr, D. F., Amer. J. Physiol., 19, 725 (1967).

${ }^{8}$ McGiff, J. C., Terragno, N. A., Strand, J. C., Lee, J. B., Lonigro, A. J., and Ng, K. K. F., Nature, 223, 742 (1969).

9 Lee, J. B., in Prostaglandin Symp. Worcester Fdn. Exp. Biol. (edit. by Ramwell and Shaw), 131 (Interscience, New York, 1967).

\section{Free Radicals in Tobacco Smoke}

THE presence of free radicals in cigarette smoke was demonstrated by Lyons et al. ${ }^{1.2}$, who trapped cigarette smoke condensate at low temperatures and examined it for unpaired electrons using electron spin resonance (ESR) techniques.

Nitroso compounds and nitrones have been reported to be spin traps for short lived species and this technique has been shown to be useful for the identification of the initial radical fragment $^{3-6}$. When $\alpha$-phenyl-N-t-butylnitrone (PBN) is used as a spin trap, the initial reactive radical $R \cdot$ adds to the nitrone to yield the longer lived nitroxide radical (equation 1).

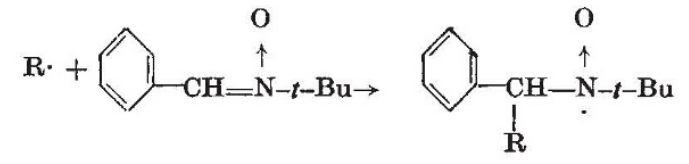

Identification of the radical trapped is derived from the values of the nitrogen and $\beta$-hydrogen hyperfine-splitting constant.

A $20 \mathrm{ml}$. glass syringe with a suitable connexion was used to aspirate the smoke directly from various cigarettes (nonfilter), cigars or pipe tobacco. The smoke was then discharged through a 'Teflon' capillary into $0.25 \mathrm{ml}$. of a $0.05 \mathrm{M}$ solution of PBN in benzene, at room temperature, in a $3 \mathrm{~mm}$ ESR cell. After de-aeration by passing a stream of argon bubbles through the solution, the ESR spectra were measured. Usually five $20 \mathrm{ml}$. smoke samples were aspirated, but in most cases as little as one $20 \mathrm{ml}$. sample was sufficient to produce a strong signal. Measurements were made at room temperature with a Varian 4500 ESR spectrometer. The sweep rates were calibrated by the spectrum of $p$-benzosemiquinone in aqueous alcohol according to the procedure of $\mathrm{Maki}^{7}$.

A quantitative evaluation of the relationship of smoke and the number of radicals was not attempted. But we found that although the visual density of the smoke from cigarettes was greatest and their benzene solutions had the deepest colour, these solutions gave very weak signals. Smoke from cigars gave the highest concentration of radicals.

One $20 \mathrm{ml}$. aspiration is roughly equivalent to one "puff", which makes this a simple and sensitive technique for the evaluation of radicals from smoke. Benzene solutions to which PBN had not been added and which had been treated similarly with smoke gave no signal on the spectrometer.

The hyperfine splitting pattern was typical for this nitroxide radical, in which the nitrogen triplet is split into doublets giving a six line spectrum ${ }^{5}$. The splitting constants were almost identical for all of the tobacco smokes : $A^{\mathrm{N}} 13.76 \pm 0.12$ gauss and $\mathrm{A}^{\mathrm{H}} 1.99 \pm 0.10$ gauss, indicating that the same type of radical was trapped in all cases. Fig. $1 A$ shows an ESR spectrum from cigar smoke. This spectrum also shows a radical which appears as a triplet with 8.01 gauss splitting. This is probably from $\alpha$-benzoyl- $\mathrm{N}$ - $t$-butylnitroxide radical arising from oxidation of $\mathrm{PBN}{ }^{5.8}$.
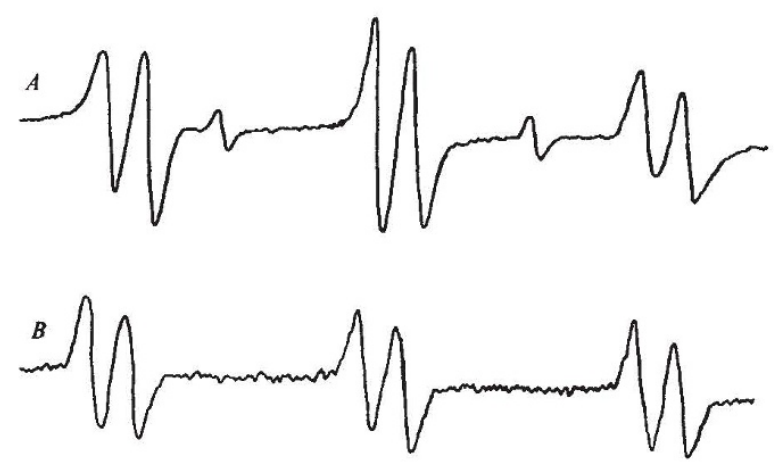

Fig. $1 A$, The ESR spectrum of the nitroxide radical from cigar smoke and phenyl- $t$-butylnitrone in benzene. $B$, The ESR spectrum of the nitroxide by ultraviolet irradiation of a solution of phenyl-t-butylnitrone in benzene containing $1 \%$ ethanol.

In our studies of nitroxide radicals from $\mathrm{PBN}$ we have noted that ultraviolet irradiation of solutions of PBN in benzene with traces of alcohols gave spectra with hyperfine splitting constants almost identical to those observed for tobacco smokes. In these examples we believe the nitroxide radicals arise from addition of $\cdot O R$ species to the nitrone ${ }^{9}$. In Fig. $1 B$ the spectrum is from the irradiated solution of $P B N$ in benzene containing a trace of ethanol. The splitting constants are $\mathrm{A}^{\mathrm{N}} 13.88$ gauss and $\mathrm{A}^{\mathrm{H}} 2.09$ gauss. We have also noted these splitting constants from the irradiation of solutions of PBN and diethylmercury or triethyl lead acetate in benzene in the presence of traces of oxygen ${ }^{9}$. When $\mathrm{R}$ in equation (1) is an alkyl group, the $\beta$-hydrogen splitting constants are of a larger order. For example, when solutions of PBN and diethylmercury in benzene were thoroughly de-aerated and irradiated with ultraviolet light, the splittings we observed were $\mathrm{A}^{\mathrm{N}} 14.58$ gauss and $\mathrm{A}^{\mathrm{H}} 3.19$ gauss which are characteristic of the nitroxide in which $\mathrm{R}=\mathrm{Et}$ (equation 1$)^{5}$.

Apparently the short lived species which attaches to the $\mathrm{C}$ atom of the nitrone may be an $\mathrm{OR}$ radical. It is not clear why these radicals seem stronger from the cigar and pipe tobaccos.

Pioneering Research Laboratory,

AARON L. BLUHM JULIUS WEINSTEIN JoHN A. Sousa

US Army Natick Laboratories, Natick, Massachusetts 01760

Received August 16; revised December 8, 1970.

${ }^{1}$ Lyons, M. J., Gibson, J. K., and Ingram, D. J. E., Nature, 181; 1003 (1958).

2 Lyons, M. J., and Spence, J. B., Brit. J. Cancer, 14, 703 (1960).

3 Iwamura, M., and Inamoto, N., Bull. Chem. Soc. Japan, 40, 702 (1967).

4 Janzen, E. G., and Blackburn, B. J., J. Amer. Chem. Soc., 90, 5909 (1968).

5 Janzen, E. G., and Blackburn, B. J., J. Amer. Chem. Soc., 91, 4481 (1969).

6 Janzen, E. G., and Gerlock, J. L., Nature, 222, 867 (1969).

7 Maki, A. H., J. Chem. Phys., 36, 1944 (1962).

8 Bluhm, A. L., and Weinstein, J., J. Amer. Chem. Soc., 92, 1444 (1970).

9 Bluhm, A. L., and Weinstein, J., Ninth Nat. Meeting of Soc. for Applied Spectroscopy, New Orleans, Louisiana, Abst. ESR Sess., 77 (1970).

\section{Possible Wind Transport of Coffee Leaf Rust across the Atlantic Ocean}

COFFEE leaf rust (Hemileia vastatrix Berk. and Br.), for long widespread in Asia and Africa, can devastate crops of Coffea arabica. The fungus spread rapidly in West Africa between 1952 and $1962^{1,2}$, but the New World seemed free from it 